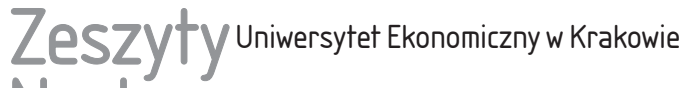 Naukowe
}

\section{The Binarisation and Monitoring of Stochastic Processes in Quality Management}

\begin{abstract}
The article examines problems that can be encountered in the monitoring and evaluation of quality control processes. Two types of product/process qualification are distinguished in quality control procedures: quality control/inspection by attributes and quality control/inspection by variables. This division also results in the division of processes. Generally, there are two types of stochastic processes: binary processes and continuous/ numerical processes. The first brings the case being described into a zero-one system. The second analyses processes with continuous random variables.

This article addresses the following issues: evaluating multidimensional stochastic processes, process binarisation methods, measuring product/process quality and applying statistical procedures to process monitoring. A comprehensive numerical example illustrating these problems is also provided.
\end{abstract}

Keywords: binary processes, quality management, process control, evaluation of multidimensional stochastic processes.

JEL Classification: C12, C19, C32, C39, C44, L15.

\section{Introduction}

The paper outlines problems that arise in monitoring quality management. The following issues are addressed: multidimensional binary and numerical eval-

Michał Major, Cracow University of Economics, Faculty of Management, Department of Statistics, Rakowicka 27,31-510 Kraków, e-mail: majorm@uek.krakow.pl 
uation of process properties, process binarisation methods, product/process quality measures, the possibility of using statistical methods, particularly cumulative sum control charts, for process monitoring.

An extensive numerical example is used to better illustrate these issues.

In managing quality, evaluating products' technical and performance features is essential, and extends to the evaluation of the production processes in which the products are manufactured. Sometimes the process is defined briefly as the development of a specific phenomenon in time (cf. Iwasiewicz 2011, p. 215). The reason for this definition is that both the state of the observed object and the relationship between phenomena can be treated as a phenomenon.

In the subject literature (Montgomery 2009) and in international standards (ISO 2859-1:1999, ISO 3951-1:2005) two methods for evaluating features are distinguished: quality control/inspection by attributes and quality control/inspection by variables.

It seems reasonable to use the term "binary evaluation of product features" and, in the case of process evaluation, "evaluation of binary processes" (cf. Iwasiewicz 2011, p. 213 and further). The character of the process studied may be due to the dichotomous state of the phenomenon being studied or to the binarisation of the multistate description thereof. The zero-one coding of a process may also be appropriate when information acquisition procedures are limited.

The situation of the numerical evaluation of product or process features is somewhat different. Here the random (diagnostic) variable is most often a continuous variable and its value is measured on a strong (ratio or interval) measurement scale. The technological process evaluated with regard to a continuous diagnostic variable can be termed either a continuous process or a quasi-continuous process. Process monitoring usually involves tracking a particular phenomenon over time, and consists of two stages (cf. Iwasiewicz 2005-2006, p. 104). The first retrieves and pre-processes information about the given objects, phenomena or relationships between them. In the second stage, data obtained in the first stage are analysed.

\section{Measuring Process Information}

The first stage yields one-dimensional or multi-dimensional time series:

$$
\left(t ; x_{t}\right), \quad t=1,2,3, \ldots,
$$

where $t$ is an interval or point on the time axis, while $x_{t}$ is the instance of a suitable random vector describing the state of the given object, phenomenon or, briefly, the process.

If the process analysis is multidimensional and the evaluation is due to $k$ partial diagnostic variables, then the resulting column vector $\mathbf{X}_{t}$ will assume the form: 


$$
\mathbf{X}_{t}=\left[\begin{array}{c}
x_{1} \\
\cdots \\
x_{j} \\
\cdots \\
x_{k}
\end{array}\right]_{t} \quad(t=1,2,3, \ldots) .
$$

In the case of binary process analysis, the values of vector (2) are determined according to the following principle:

$$
x_{j t}=\left\{\begin{array}{ll}
0 & \text { if process state meets requirements } \\
1 & \text { if process state does not meet requirements }
\end{array} .\right.
$$

The set of values of each diagnostic variable $X_{j}$ is a two-element set $X_{j}^{0}=\{0 ; 1\}$, out of which two subsets are distinguished: a subset of the desired values $X_{j}^{+}=\{0\}$ and a subset of undesirable values $X_{j}^{-}=\{1\}$.

If the process represented by continuous diagnostic variables is analysed, then the vector (2) values are the real numbers resulting from the measurement on a strong scale. Then meeting or not meeting the specific process requirements depends on other factors such as the type of diagnostic variable ${ }^{1}$ (quality nominant, quality stimulant, quality destimulant ${ }^{2}$ ) and the associated tolerance interval structure (two-sided, one-sided). Quality requirements are formulated in the form of tolerance range $X_{j+}$, which is equivalent to the set of allowable values $X_{j}^{+}$. The tolerance range form depends on the diagnostic variable type and on the technological and/or substantive requirements for the process under analysis. If $j$-th diagnostic variable is treated as the quality nominant, then the tolerance range is limited on both sides by $x_{j . d}$ and $x_{j . g}$ and assumes the form:

$$
X_{j+}=\left[x_{j . d} ; x_{j . g}\right] \text {. }
$$

In range (4), the optimal (nominal, most desirable) value is $x_{j . N} \in X_{j+}$.

If the diagnostic variable being studied is a quality destimulant, then the tolerance range is limited on the right side by $x_{j . g}$ and assumes the form:

$$
X_{j+}=\left[a ; x_{j . g}\right]
$$

if, however, the diagnostic variable is a quality stimulant, then the tolerance range is limited on the left side by $x_{j . d}$ and then assumes the form:

$$
X_{j+}=\left[x_{j . d} ; b\right] .
$$

${ }^{1}$ It is typically assumed that the distribution of such a variable is approximated by the normal distribution with parameters $\mu$ and $\sigma$, which are the expected value and standard deviation of variable $X_{j}\left(X_{j} \sim N(\mu ; \sigma)\right)$,

${ }^{2}$ See more (Major 2015c, p. 71-76), see also: (Hellwig 1968, p. 48; Borys 1978, p. 118; 1980, p. 31-33; Iwasiewicz 2005, p. 36-41; Bąk 1999, p. 34-37; Taksonomiczna analiza... 2000, p. 76-82). 
Parameters $x_{j . d}$ and $x_{j . g}$ should be interpreted as the $j$-th variable's acceptable minimum and maximum. In turn, $a$ and $b$ are not constraints in terms of quality requirements. They depend on the formal properties of the adopted measurement scale, or on the technical properties of the measurement instrumentation used. If, for example, the percentage concentration of a particular ingredient in a product is being evaluated, then $a=0 \%, b=100 \%$.

\section{Integration of Partial Process Evaluations}

Once the column vector or type (2) vectors have been obtained, the partial process evaluations must be integrated. This can be done in two ways. The first is to analyse the process state for each $j$-th diagnostic variable $(j=1, \ldots, k)$ separately, and to statistically integrate the individual results at the final analysis stage of the process. The second way aims to integrate the results by developing synthetic (integrated) process characteristics already at the partial information collection stage. The overall evaluation of the process is then based on a statistical analysis of the synthetic (integrated) process evaluations.

One way to integrate data at the partial information collection stage is to compare the subsequent column vectors (2) with the reference column vector $\mathbf{X}_{0}$ in the general form:

$$
\mathbf{X}_{0}=\left[\begin{array}{c}
x_{1.0} \\
\cdots \\
x_{j .0} \\
\cdots \\
x_{k .0}
\end{array}\right] .
$$

The pattern vector values depend on the process characteristics. In the case of a binary process, in accordance with rule (3), all coordinates of vector $\mathbf{X}_{0}$ are equal to the values of subset $X_{j}^{+}=\{0\}$ and amount to $x_{j .0}=0(j=1, \ldots, k)$. The process state vectors (2) can be compared with the pattern vector by using statistics $D_{t}$, with values calculated from the formula (Iwasiewicz 2011, p. 217):

$$
d_{t}=\sum_{j=1}^{k}\left(x_{j . t}-x_{j .0}\right)=\sum_{j=1}^{k} x_{j . t} \quad(t=1,2,3, \ldots) .
$$

Statistics $D_{t}$ can assume values from set $D^{0}=\{0,1,2, \ldots, k\}$ denoting the number of incompatibilities between subsequent process state vectors $\mathbf{X}_{t}$ and pattern vector $\mathbf{X}_{0}$. Probability distribution set on individual values of these statistics allows for further evaluation of the process state ${ }^{3}$.

\footnotetext{
${ }^{3}$ The most common distributions used in practice include binomial and Poisson distributions.
} 
Using an algorithm for dealing with continuous processes is somewhat different, and can be handled in two ways. The first converts the continuous variable to the binary variable.

Then the new partial variable $X_{j}^{\prime}$ will take values according to the rule:

$$
x_{j t}^{\prime}=\left\{\begin{array}{lll}
0 & \text { if } & x_{j t} \in X_{j+} \\
1 & \text { if } & x_{j t} \notin X_{j+}
\end{array}\right.
$$

where $X_{j+}$ means the tolerance range of the $j$-th continuous diagnostic variable.

The second solution is to define the values of the pattern vector. How the pattern vector's values are defined, with its coordinates confronted with process state vectors $\mathbf{X}_{t}$, is slightly different in continuous processes. Pattern vector values $x_{0 . j}(\mathrm{j}=1, \ldots, k)$ are created according to the following rule ${ }^{4}$ :

where:

$$
x_{0 . j}= \begin{cases}x_{j \cdot \max } & \text { if } X_{j}-\text { stimulant } \\ x_{j \cdot \min } & \text { if } X_{j}-\text { destimulant } \\ x_{j . N} & \text { if } X_{j}-\text { nominant }\end{cases}
$$

$x_{j . N}$ - the optimum (nominal, most desirable) value of the variable being the quality nominant,

$x_{j \text { min }}\left(x_{j \text { max }}\right)$ - the theoretical minimum (maximum) value of the $j$-th diagnostic variable. When the tolerance range is defined as in (5) or (6), then $x_{j \text { min }}=a$, and $x_{j \text { max }}=b$.

The reference pattern design becomes simpler when the diagnostic variables describing the products being tested are subjected to stimulation (a transformation that brings the diagnostic variables under analysis down to quality stimulants). Then the $j$-th coordinate of the reference pattern will be determined as follows:

$$
x_{0 . j}=x_{j, \max } .
$$

Another significant simplification may consist in subjecting the diagnostic variables to a normalisation process, especially of a type that guarantees a uniform order of magnitude in the range $[0,1]$. Such a condition is fulfilled by zero unitarisation, for example. As a result, the values of the variables are transformed to the range $[0,1]$. The column pattern vector is then a vector $k$ values of one in the form:

$$
\mathbf{X}_{0}=\left[\begin{array}{c}
x_{1.0}=1 \\
\cdots \\
x_{j .0}=1 \\
\cdots \\
x_{k .0}=1
\end{array}\right] .
$$

${ }^{4}$ The reference pattern can be real object (one of ones being evaluated) or a theoretical (virtual) object. See more (Major 2015c, p. 92-93). 
A separate issue is how to compare the process state vectors with the pattern vector. A number of methods using various distance measures have been reported (eg. Major 2015c, p. 85-95, 103-106; Walesiak 2002, p. 35, 54-59). The most popular, and simplest method, uses Euclid's metric. If the reference pattern is a vector of ones, the distance between it and the process state vectors is calculated according to this formula (Major 2015c, p. 104):

$$
d_{t .0}=\sqrt{\sum_{j=1}^{k} w_{j}\left(q_{j t}-1\right)^{2}},
$$

where:

$d_{t .0}$ - the distance between the state of the process in time $t$, and the pattern vector,

$q_{j t}$ - the normalised value of the $j$-th variable $\left(q_{j t} \in[0,1]\right)$,

$w_{j}$ - the weight factor assigned to the $j$-th diagnostic variable $5\left(\sum_{j=1}^{k} w_{j}=1\right)$.

Assuming that the sum of the weights assigned to the diagnostic variables is 1 , the set of values generated by metric (13) will be in the range $[0,1]$. The closer the metric value is to zero, the more desirable will be the final state of the process, and the further away from the ideal the closer the value is to 1 .

\section{Process Evaluation}

As noted earlier, process evaluation depends on the process type and the resulting category of the variable that aggregates partial evaluations. In the relevant literature (Iwasiewicz 2011, p. 218) there are usually two evaluation categories identified:

- by attributes,

- multi-state (multi-level).

In the first case, only two states of the process (see Iwasiewicz 1985, p. 71) are recognised:

- in control (running correctly, as required),

- out of control (running incorrectly, not as required).

In the latter case, the number of process states depends on the set of values of the partial evaluation aggregating variable. In binary processes, such states can be maximum $k$ ( $k$ - number of variables), but in continuous processes theoretically there are infinitely many.

\footnotetext{
${ }^{5}$ Assuming equal validity of the variables, the weight factor can be omitted or assumed to be $1 / k$.
} 
Procedures used to evaluate (or monitor) processes most often generate evaluations by attributes ${ }^{6}$. Sometimes multi-stage evaluations are transformed to evaluations by attributes (the so-called dichotomisation of diagnostic variables). This is in line with the intuitive approach to the problem, whereby a quality manager is usually interested in whether the process is out of control, rather than defining the extent of defectiveness.

A. Iwasiewicz has proposed the following zero-one synthetic variable $Y_{t}$, which assumes values according to the rule (Iwasiewicz 2011, p. 218):

$$
y_{t}= \begin{cases}0 & \text { if } \mathbf{X}_{t} \varphi \mathbf{X}_{0} \\ 1 & \text { if } \mathbf{X}_{t} \bar{\varphi} \mathbf{X}_{0}\end{cases}
$$

where:

$\mathbf{X}_{t} \varphi \mathbf{X}_{0}$ denotes the instance of conformity between vectors $\mathbf{X}_{t}$ and $\mathbf{X}_{0}$,

$\mathbf{X}_{t} \bar{\varphi} \mathbf{X}_{0}$ denotes the instance of nonconformity between vectors $\mathbf{X}_{t}$ and $\mathbf{X}_{0}$,

$\varphi(\bar{\varphi})$ - the relationship of conformity (or nonconformity).

Like partial variables, the synthetic variable $Y_{t}$ has a two-element set of values $Y^{0}=\{0 ; 1\}$, which includes two single-element subsets: a subset of desired values $Y^{+}=\{0\}$ and a subset of undesired values $Y^{-}=\{1\}$.

It is important how the relationship of conformity $(\varphi)$ between the process state vector and the pattern vector is defined. The basic parameters affecting the type of relationship include the number of diagnostic variables tested $(k)$ and the maximum allowable number of nonconformities $(r: r \leq k)$. The most rigorous class of relationships is the relation $(k ; 0)$. To qualify a tested stochastic as in control, its all $k$ partial diagnostic variables must be conforming. This is the case when all partial diagnostic variables describe relatively relevant critical features of the object (be it a product or something else) ${ }^{7}$. If the variable or partial variables describe irrelevant features of the object ${ }^{8}$, it is then acceptable to use a relationship of the $(k ; 1 \leq r \leq \mathrm{k})$ class. In this case, however, it should be clarified whether the relation applies to all variables or only to its particular subset. For example, $\varphi\left(k ; 1_{2}\right)$ means that the conformity relationship does not necessarily apply to the diagnostic variable 2 , and $\varphi(k ; 1)$ means that one nonconformity is acceptable with regard to any $j$-th variable $(j=1, \ldots, k)$.

${ }^{6}$ An obvious example is the control chart that enables signalling the process' correctness or defectiveness with a certain probability of error.

7 The notion of critical product feature or relevant product feature is related to the nature of the product's defect. A critical defect may lead to hazardous conditions when the product is used, or significantly reduces a product's ability to perform certain functions. A relevant defect disables or reduces the product's usability. See more (Słownik jakości 1980, p. 33; cf. Słownik jakości 1968).

${ }^{8}$ The notion of irrelevant feature is related to the definition of irrelevant defect - that is, such which has little effect on the product's performance and which does not diminish its usability for its intended purpose (after Słownik jakości 1980, p. 33). 
Suppose now that a continuous stochastic process is evaluated. The conformity between the process state vector and the pattern vector (11) is evaluated on the basis of metric (12). The chronological partial results of the process state may then be aggregated according to the formula:

$$
y_{t}=\left\{\begin{array}{lll}
0 & \text { if } & d_{t .0} \leq \delta_{t .0} \\
1 & \text { if } & d_{t .0}>\delta_{t .0}
\end{array}\right.
$$

where:

$d_{t .0}$ is the synthetic distance between the process state vector at time $t$ and the pattern vector and

$\delta_{t .0}\left(0 \leq \delta_{t .0} \leq 1\right)$ is the maximum allowable (acceptable) synthetic distance from the reference pattern.

The parameter $\delta_{t .0}$ should depend on the tolerance limits of the diagnostic variables under analysis 9 . Since it has been assumed that the diagnostic variables were normalised by the zero unitarisastion method, their values, as well as the tolerance range limits, are in the range $[0,1]$. Each normalised $j$-th diagnostic variable is then a quality stimulant with a tolerance range for the form:

$$
Q_{j+}=\left[q_{j . d} ; 1\right],
$$

where:

$q_{j . d}$ - the normalised lower limit of the $j$-th diagnostic variable's tolerance range.

From here, the maximum synthetic distance from the reference pattern can be calculated:

$$
\delta_{t .0}=\sqrt{\sum_{j=1}^{k} w_{j}\left(q_{j d}-1\right)^{2}} .
$$

The weakness of this solution is that it does not allow one to differentiate between conformity classes, as is the case with binary processes. Let us note that by using the aggregation of type (15), we take into account all $k$ partial variables. One possible solution to mitigate the conformity relationship in this case may be the appropriate selection of the weights of partial variables and of parameter $\delta$. As is known from the literature: (Willmott \& Grimshaw 1969; Wishart 1969; Kolonko 1980, p. 41; Borys 1984, p. 319; Abrahamowicz 1985, p. 188-243; Grabiński, Wydymus and Zeliaś 1989, p. 25-27; Bąk 1999, p. 44-46; Taksonomiczna analiza... 2000, p. 45-50; Major 2015, p. 76-80), the appropriate selection of the variables' weights is not an obvious process and requires serious knowledge

${ }^{9}$ Parameter $\delta$ can also be valued arbitrarily on the basis of the technical and substantive conditions of the the process under study. In the simplest situation, the $\delta$ value can be assumed as 0.5 , which means that, at most, half of the maximum distance between the current vector and the pattern vector is acceptable. 
of the subject matter. However, this problem can be avoided by prior dichotomising the process at the information acquisition stage.

\section{Measures of Product/Process Quality}

The state of a monitored process is usually indicated by the average level of the observed phenomenon and its variability. For binary evaluations of processes, both of these characteristics are tracked simultaneously by observing parameter $p$. This is because when random variable has a zero-one distribution, the expected value and variance are respectively $p$ and $q=p(1-p)$. Parameter $p$ is defined as the probability of a random event, the occurrence of which will lead the monitored process to an undesirable state. If a process is evaluated with regard to a single $j$-th diagnostic variable, i.e. when the partial level of the process is evaluated, then:

$$
p\left(X_{j}\right)=P\left(X_{j} \in X_{j}^{-}\right)=P\left(X_{j} \notin X_{j}^{+}\right)=P\left(X_{j}=1\right), \quad(j=1, \ldots, k) .
$$

If, on the other hand, a process state is evaluated with regard to synthetic (aggregate) variable $Y$ in the form of (14), then, similarly:

$$
p(Y)=P\left(Y \in Y^{-}\right)=P\left(Y \notin Y^{+}\right)=P(Y=1) .
$$

In the relevant literature (Iwasiewicz 1999, p. 136-140; 2005, p. 59-87), characteristic (18) is called the partial defect (defectiveness), while statistic (19) is called the aggregate defect of the product or process. These inverse measures - inverse because from the perspective of process quality, the smallest possible values of this parameter are desirable - belong to one of the two basic performance quality measures ${ }^{10}$.

Measures (18) and (19) can be replaced by other non-inverse measures - partial correctness $q\left(X_{j}\right)$ and aggregate correctness $q(Y)$. Then:

$$
\begin{gathered}
q\left(X_{j}\right)=P\left(X_{j} \in X_{j}^{+}\right)=P\left(X_{j} \notin X_{j}^{-}\right)=P\left(X_{j}=0\right), \quad(j=1, \ldots, k), \\
q(Y)=P\left(Y \in Y^{+}\right)=P\left(Y \notin Y^{-}\right)=P(Y=0) .
\end{gathered}
$$

There are the following relationships between these measures:

$$
\begin{gathered}
p\left(X_{j}\right)+q\left(X_{j}\right)=1, \\
p(Y)+q(Y)=1 .
\end{gathered}
$$

Aggregate defectiveness and correctness depend on the number of diagnostic variables and on the conformity relationship class. There are the following dependences:

${ }^{10}$ The other quality measure is the number of defects in the product unit. 


$$
\begin{aligned}
& p(Y)=P(Y=1)=p\left(\mathbf{X}_{t} ; k, \varphi\right)=\mathrm{P}\left(\mathbf{X}_{t} \bar{\varphi} \mathbf{X}_{0}\right), \\
& q(Y)=P(Y=0)=q\left(\mathbf{X}_{t} ; k, \varphi\right)=P\left(\mathbf{X}_{t} \varphi \mathbf{X}_{0}\right) .
\end{aligned}
$$

Symbols $\mathbf{X}_{t} \varphi \mathbf{X}_{0}$ and $\mathbf{X}_{t} \bar{\varphi} \mathbf{X}_{0}$ have the same meaning as in formula (14) and indicate the conformity, or lack thereof, between vectors $\mathbf{X}_{t}$ and $\mathbf{X}_{0}$.

As mentioned above, the most demanding conformity relationship is that of the $(k ; 0)$ class, the process being acceptable only if all partial requirements are met. If the process is binary and evaluated for $k$ partial variables, then $2^{k}$ possible sequences of the evaluated process can be distinguished, and the fraction of acceptable sequences of partial evaluations is $1 / 2^{k}$. As can be easily proven, this fraction will approach zero as the number $k$ of partial evaluations increases. This means the likelihood of a negative evaluation of the analysed process will increase.

In addition, it may be observed that (Iwasiewicz 2011, p. 225):

$$
p(Y)=p\left(\mathbf{X}_{i} ; k, \varphi\right)=1-\prod_{j=1}^{k} q\left(X_{j}\right)=1-\prod_{j=1}^{k}\left[1-p\left(X_{j}\right)\right] .
$$

This means that to calculate the aggregate defectiveness in the space of $k$ diagnostic variables, the product of all partial correctnesses must be subtracted from one.

If the partial defectivenesses of each partial variables are identical and are $p(X)$, then formula (26) is reduced to:

$$
p(Y)=p\left(\mathbf{X}_{t} ; k, \varphi\right)=1-[1-p(X)]^{k} .
$$

From equation (27) the minimum number of criteria $k$ can be determined, which guarantees the process under analysis will be disqualified. The class $(k ; 0)$ process shall be disqualified when the maximum allowable aggregate defectiveness $p_{0}$ is exceeded. This means the following condition must be met:

$$
1-[1-p(X)]^{k}>p_{0} .
$$

After the appropriate transformations, the following can be obtained:

$$
k>\frac{\lg \left(1-p_{0}\right)}{\lg [1-p(X)]} .
$$

Table 1 shows the example $k$ values calculated for selected $p_{0}$ and $p(X)$. It was assumed for the calculations that $p(X)=0.01,(0.01), 0.06$ and $p_{0}=0.05,(0.05), 0.5$.

Rounding the resultant values $k$ up to the nearest integer produces the minimum number of variables with which the evaluated process shall be disqualified. For example, the maximum allowable defectiveness $p_{0}=0.05$ will be exceeded if the partial defectiveness is 0.01 , and the number of variables $k$ is 6 or more. 
Table 1. The Minimum Number of Variables that Disqualifies a Process as a Function of Maximum Aggregate Defectiveness and Partial Defectiveness

\begin{tabular}{|c|c|c|c|c|c|c|c|c|c|}
\hline \multirow{2}{*}{$\begin{array}{c}p(X) \\
(\%)\end{array}$} & \multicolumn{9}{|c|}{$p_{0}$} \\
\cline { 2 - 11 } & 0.05 & 0.10 & 0.15 & 0.20 & 0.25 & 0.30 & 0.40 & 0.45 & 0.50 \\
\cline { 2 - 10 } & \multicolumn{9}{|c|}{$k$} \\
\hline 0.01 & 5.10 & 10.48 & 16.17 & 22.20 & 28.62 & 35.49 & 50.83 & 59.48 & 68.97 \\
\hline 0.02 & 2.54 & 5.22 & 8.04 & 11.05 & 14.24 & 17.65 & 25.29 & 29.59 & 34.31 \\
\hline 0.03 & 1.68 & 3.46 & 5.34 & 7.33 & 9.44 & 11.71 & 16.77 & 19.63 & 22.76 \\
\hline 0.04 & 1.26 & 2.58 & 3.98 & 5.47 & 7.05 & 8.74 & 12.51 & 14.64 & 16.98 \\
\hline 0.05 & 1.00 & 2.05 & 3.17 & 4.35 & 5.61 & 6.95 & 9.96 & 11.66 & 13.51 \\
\hline 0.06 & 0.83 & 1.70 & 2.63 & 3.61 & 4.65 & 5.76 & 8.26 & 9.66 & 11.20 \\
\hline
\end{tabular}

Source: the author.

Equation (27) can also become the basis for determining the maximum average partial defectiveness at which a specific aggregate variability is not exceeded. By transforming this equation, we get:

$$
[1-p(X)]^{k}=1-p(Y) \Rightarrow 1-p(X)=\sqrt[k]{1-p(Y)} \Rightarrow p(X)=1-\sqrt[k]{1-p(Y)} .
$$

If partial requirements are not critical, then the conformity relationship may be relaxed to $(k ; 1)$ class. The process will then be accepted if at least $k-1$ of $k$ partial requirements are met, and will be disqualified if at least two partial requirements are not met.

If we assume that all partial defectivenesses are at the same level $p(X)$, and the conformity relationship is of $(k ; 1)$ class, then the aggregate defectiveness will be described by the formula:

$$
p(Y)=p\left(\mathbf{X}_{t} ; k, 1\right)=1-[1-p(X)]^{k}-k \cdot p(X) \cdot[1-p(X)]^{k+1} .
$$

The situation is somewhat different when the conformity relationship is reduced to a $(k ; 1 r)$ class, where $r=1, \ldots, k$, is the number of the variable relative to which no relation of conformity is required. This is equivalent to the reduction of the $r$-th partial criterion and the introduction of the $(k-1 ; 0)$ class relationship. The aggregate defectiveness will then be determined by the formula:

$$
p(Y)=p\left(\mathbf{X}_{t} ; k, 1 r\right)=1-\prod_{j=1}^{k} q\left(X_{j \neq r}\right)=1-\prod_{j=1}^{k}\left[1-p\left(X_{j \neq r}\right)\right] .
$$

Let us now proceed to the definition of partial defectiveness for the $j$-th continuous diagnostic variable. Then, using the previously defined symbols, we can save:

$$
p\left(X_{j}\right)=P\left(X_{j} \notin X_{j+}\right) .
$$


After defining partial defectivenesses using formula (26), the aggregate defectiveness can be determined.

It is worth noting that according to measurement theory, the measurement scale and secondary dichotomisation of the diagnostic variable can be weakened. Then the defectiveness definition (33) should be replaced by definition (18), and the evaluated process becomes a binary process.

\section{Example of Aggregate Product Quality Assessment}

When evaluating the manufacture of towing ropes, the conformity of their parameters is checked against the requirements of (http://federacja-konsumentow. org.pl/download/LINKI\%202.doc, accessed: 22.08.2017):

1) The Road Traffic Law, Art. 31.1 pp. 7: features: tow length, rope colour,

2) requirements included in WT/008/PIMOT/93 (“Towing Ropes. Use safety requirements and tests"): features: user manual, tensile strength, ease of assembly/ disassembly.

Quantification of these features produces the following 5 diagnostic variables:

$X_{1}$ - tow length in meters, evaluation by variables (continuous random variable), tolerance range limited on both sides: $X_{j+}=[4 \mathrm{~m} ; 6 \mathrm{~m}]$;

$X_{2}$ - rope colour, evaluation by attributes, binary random variable: $X_{2}=0$ if the rope has white/red or orange stripes over its entire length or has a red or yellow warning flag; $X_{2}=1$ if the rope deviates significantly from the reference pattern with regard to the colour or flag;

$X_{3}$ - user manual, evaluation by attributes, binary random variable: $X_{3}=0$ if a manual is enclosed with each product that contains rope fixing and towing technique details; $X_{3}=1$ if no manual is enclosed with the product, or the enclosed manual is incomplete with regard to rope fixing and towing technique details;

$X_{4}$ - the rope's tensile strength in 20 seconds (in daN/20s), evaluation by variables (continuous random variable), tolerance range limited on one side (the left side) by $x_{j . d}$. Parameter $x_{j . d}$ is defined by separate regulations and depends on the weight of the vehicle being towed. If it does not exceed $1500 \mathrm{~kg}$, then $x_{j . d}=1200$ daN/20s. If it does, then $x_{j . d .} \geq 1500 \mathrm{daN} / 20 \mathrm{~s}$;

$X_{5}$ - ease of assembly/disassembly, evaluation by attributes, binary random variable: $X_{5}=0$ if the rope is easy to assemble and disassemble after strength tests, the fasteners are not deformed; $X_{5}=1$ if there are obstacles during the rope's assembly/disassembly, it is locked, and fasteners are permanently deformed.

It should be noted that the set of 5 variables includes zero-one variables $\left(X_{2}, X_{3}, X_{5}\right)$ as well as variables measured on strong measuring scales $\left(X_{1}, X_{4}\right)$. The process is therefore mixed, i.e. binary for variables: $X_{2}, X_{3}, X_{5}$ and continuous 
for variables $X_{1}$ and $X_{4}$. As noted in the article, variables $X_{1}, X_{4}$ can be transformed according to rule (18). Then the new variable $X_{1}^{\prime}=0$ if $x_{1 t} \in[4 m ; 6 m]$ and, accordingly, $X_{1}^{\prime}=1$ if $x_{1 t} \notin[4 m ; 6 m]$. The values of variable $X_{4}$ can also be similarly converted. Then $X_{4}^{\prime}=0$ if $x_{1 t} \geq x_{j . d}$ and $X_{4}^{\prime}=1$ if $x_{4 t}<x_{j . d}$. The resulting process will be binary in the space of 5 partial evaluations.

Let us assume further that, based on the technological process documentation, partial defectivenesses have been estimated. They are, respectively:

$$
p\left(X_{1}\right)=0.0002, p\left(X_{2}\right)=0.0004, p\left(X_{3}\right)=0.001, p\left(X_{4}\right)=0.0003, p\left(X_{5}\right)=0.0012 .
$$

With the assumed conformity class $(5 ; 0)$, the aggregate defectiveness will be in accordance with formula (26):

$$
\begin{gathered}
p(Y)=1-(1-0.0002) \cdot(1-0.0004) \cdot(1-0.001) \cdot(1-0.0003) \cdot(1-0.0012)= \\
=1-(0.9998 \cdot 0.9996 \cdot 0.999 \cdot 0.9997 \cdot 0.9988)= \\
=1-0.996903=0.003097(0.3097 \% \text { or } 3.097 \%) .
\end{gathered}
$$

This means that, on average, 31 out of 10,000 towing ropes have deviations from the adopted requirements.

Assume that the manufacturer's ambition is to reduce the aggregate defectiveness to 1 per mille. Can this be achieved by increasing the partial correctness with regard to criterion 3 ? If so, what should be the maximum partial defectiveness $p\left(X_{3}\right)$ ?

To answer this question, the following inequality must be solved with respect to $p\left(X_{3}\right)$ :

$$
\begin{gathered}
p(Y)=1-\left\{(1-0.0002) \cdot(1-0.0004) \cdot\left[1-p\left(X_{3}\right)\right] \cdot(1-0.0003) \cdot(1-0.0012)\right\} \leq 0.001 \\
1-\left\{0.9998 \cdot 0.9996 \cdot\left[1-p\left(X_{3}\right)\right] \cdot 0.9997 \cdot 0.9988\right\} \leq 0.001 \\
1-\left\{0.997901 \cdot\left[1-p\left(X_{3}\right)\right]\right\} \leq 0.001 \\
1-0.997901+0.997901 \cdot p\left(X_{3}\right) \leq 0.001 \\
0.002099+0.997901 \cdot p\left(X_{3}\right) \leq 0.001 \\
p\left(X_{3}\right)=(0.001-0.002099) / 0.997901=-0,0011 \notin[0,1] .
\end{gathered}
$$

Since the resulting parameter $p\left(X_{3}\right)$ does not meet the basic assumption of the defectiveness definition, according to which it is a number from the $[0,1]$ range, it should be stated the aggregate defectiveness cannot be reduced to 1 per mille by decreasing the partial defectiveness criterion 3 .

Let us note that even if we assume that $p\left(X_{3}\right)=0$, then the aggregate defectiveness will be:

$$
\begin{gathered}
p(Y)=1-\{(1-0.0002) \cdot(1-0.0004) \cdot(1-0) \cdot(1-0.0003) \cdot(1-0.0012)\}= \\
=1-(0.9998 \cdot 0.9996 \cdot 1 \cdot 0.9997 \cdot 0.9988)=1-0.997901=0.002099>0.001 .
\end{gathered}
$$

This means that even if 100 percent of the requirements for the third feature (user manual) are fulfilled, and no improvement occurs in the partial correctnesses 
with regard to the remaining criteria, ca. 21 out of 10,000 ropes may not meet the required specifications.

A solution may be to reduce other partial defectivenesses so that the aggregate defectiveness does not exceed the preset limit of 1 per mille.

Assuming that the target partial defectivenesses are equal $p(X)=p\left(X_{1}\right)=p\left(X_{2}\right)=$ $=p\left(X_{3}\right)=p\left(X_{4}\right)=p\left(X_{5}\right)$, by using formula (27), the maximum acceptable average partial defectiveness can be determined:

$$
p(X)=1-\sqrt[5]{1-0.001}=1-\sqrt[5]{0.999}=0.0002 \quad(0.02 \% \text { or } 0.2 \%) .
$$

The result demonstrates that in order to ensure that no more than one in ten thousand ropes deviates from the adopted reference pattern, the average partial defectiveness cannot exceed 0.2 per mille. However, this requires compliance with the difficult assumption that all partial defectivenesses are equal.

Another way to reduce the defectiveness is to ease the conformity class from $(k=5 ; 0)$ to $(k=5 ; 1)$ or $(k=5 ; 2)$. However, this is not possible when the space of the number and type of criteria required are defined by law and not by individual contract with the recipient.

\section{Closing Remarks}

The resulting partial diagnostic variables $X_{j}(j=1, \ldots, k)$ and the synthetic variables $Y_{t}$ created in accordance with one of rules (14) or (15) can provide the basis for further process analysis based on a statistical process monitoring procedure. The relevant literature (e.g. Montgomery 2009, Qiu 2013) reports several different procedures for this purpose. The best-known and most widespread tools are control charts. The primary feature of all tools identified as control charts is that they serve to record, process, and analyse the source data describing the state of the process. The aim of such an analysis is to detect systematic (non-random) changes in the process, which results in the emission of a corresponding process state signal. Since in the aricle it was assumed that in subsequent moments of the process' tracking $t(t=1,2,3, \ldots)$ individual elements of the process are evaluated as represented by individual values of the synthetic variable $Y_{t}$ in the form of (14) or (15), it would seem most rational to use a sequential procedure ${ }^{11}$ and, in

11 These procedures are based on the sequential verification of statistical hypotheses, which is an alternative to the classical theory of hypothesis verification. Their design was derived from the works of Abraham Wald (1902-1950) (Wald 1945, 1947). 
particular, of cumulative sum control charts with the process acceptance ${ }^{12}$. This chart can be used in either a graphical or numerical version.

Sequential analysis theory is reduced to the random sampling of individual elements or small sets of the general population, in each case resolving whether the information so far acquired allows for a specific decision. Such a decision may result in the acceptance or disqualification of the process being evaluated. A third option is also available, whereby the decision is postponed until the information resource extended by yet another unit will allow for an alternative choice. Such decisions are made with two specific risks of error: Type I $(\alpha)$ and Type II ( $\beta$ ). The hypotheses to be tested are in the following form (Iwasiewicz 2011, p. 233; Iwasiewicz, Paszek \& Steczkowski 1988, p. 101; Wald 1945, p. 158):

$$
\begin{aligned}
& H_{0}: p(Y)=p_{0}(Y), \\
& H_{1}: p(Y)=p_{1}(Y),
\end{aligned}
$$

while $p_{0}(Y)<p_{1}(Y)$.

Parameters $p_{0}(Y)$ and $p_{1}(Y)$ denote, respectively, the maximum allowable and the minimum disqualifying aggregate defectivenesses. Range $\left[p_{0}(Y) ; p_{1}(Y)\right]$ with length $p_{1}(Y)-p_{0}(Y)=\Delta p$ is referred to as the interval of uncertain decisions, in which the information obtained does not allow convincing acceptance of either hypothesis, $H_{0}$ or $H_{1}$. Hypothesis $H_{0}$ is adopted at a risk of error no greater than $\beta$, while hypothesis $H_{1}$ is adopted at a risk no higher than $\alpha$.

A description of the use of the cumulative sum control chart with the possibility of accepting the process for monitoring binary processes can be found in (Iwasiewicz 2008-2009, 2011, Major 2017).

The procedures described in this article are among the issues related to product quality evaluation and the related analysis of stochastic processes. These processes may be related to problems arising in the production of usable products. They can also be applied in the analysis of other processes such as stock exchange processes, service processes, teaching and learning processes, etc.

In all these cases, there are two possible means of evaluating a process: by attributes and by variables. As a rule, this evaluation is a multi-criterion evaluation, where the need appears for the aggregation of particle data in the form of synthetic measures. A separate issue is whether the aggregation should be binary or numeric. After considering the many benefits and drawbacks, it can be concluded that in the age of digitisation, which in its foundations is based on a zero-one system, binarisation of processes is the most appropriate course of action.

12 See: (Major 1997, p. 47-54; Iwasiewicz 2008-2009, 2011; Major 2015a, p. 25-43; 2015b, p. 223-238; 2016, p. 47-60; 2017, p. 87-105). 


\section{Bibliography}

Abrahamowicz M. (1985), Porzadkowanie obiektów $w$ wielowymiarowych przestrzeniach zmiennych diagnostycznych [Organising objects in multidimensional spaces of diagnostic variables], doctoral thesis, Akademia Ekonomiczna w Krakowie, Kraków.

Bąk A. (1999), Modelowanie symulacyjne wybranych algorytmów wielowymiarowej analizy porównawczej w języku $C++$ [Simulation modelling of selected algorithms for multivariate comparative analysis in $\mathrm{C}++]$, Wydawnictwo Akademii Ekonomicznej im. O. Lanego we Wrocławiu, Wrocław.

Borys T. (1978), Metody normowania cech statystycznych w badaniach porównawczych [Methods of normalising statistical features in comparative research], "Przegląd Statystyczny", no. 2.

Borys T. (1980), Elementy teorii jakości [Elements of the theory of quality], PWN, Warszawa.

Borys T. (1984), Kategoria jakości w statystycznej analizie porównawczej [The category of quality in statistical comparative analysis], Prace Naukowe AE we Wrocławiu no. 284, seria: Monografie i Opracowania, no. 23, Wrocław.

Grabiński T., Wydymus S., Zeliaś A. (1989), Metody taksonomii numerycznej w modelowaniu zjawisk społeczno-gospodarczych [Methods of numerical taxonomy in modelling socio-economic phenomena], PWN, Warszawa.

Hellwig Z. (1968), Zastosowanie metody taksonomicznej do typologicznego podziału krajów ze względu na poziom ich rozwoju i strukturę wykwalifikowanych kadr [Application of the taxonomic method to the typological division of countries by level of development and the structure of qualified personnel], "Przegląd Statystyczny", no. 4.

ISO 2859-1:1999 (1999), Sampling Procedures for Inspection by Attributes - Part 1: Sampling schemes indexed by acceptance quality limit (AQL) for lot-by-lot inspection.

ISO 3951-1:2005 (2005), Sampling Procedures for Inspection by Variables - Part 1: Specification for single sampling plans indexed by acceptance quality limit (AQL) for lot-by-lot inspection for a single quality characteristic and a single AQL.

Iwasiewicz A. (1985), Statystyczna kontrola jakości w toku produkcji. Systemy i procedury [Statistical quality control in the course of production. Systems and procedures], PWN, Warszawa.

Iwasiewicz A. (1999), Zarzadzanie jakościa - podstawowe problemy i metody (Quality management - elementary problems and methods), PWN, Warszawa-Kraków.

Iwasiewicz A. (2005), Zarządzanie jakością w przykładach i zadaniach [Quality management in examples and tasks], Sląskie Wydawnictwo Naukowe w Tychach, Tychy.

Iwasiewicz A. (2005-2006), Monitorowanie procesów binarnych [Monitoring of the binary processes], "Folia Oeconomica Cracoviensia", vol. XLVI-XLVII, Kraków.

Iwasiewicz A. (2008-2009), Monitorowanie procesów binarnych za pomoca kart kontrolnych sum skumulowanych [Monitoring binary processes with the use of cumulative sum control charts], "Folia Oeconomica Cracoviensia", vol. XLIX-L, Kraków.

Iwasiewicz A. (2011), Analiza wielowymiarowych procesów binarnych jako metoda wspomagania decyzji menedżerskich $w$ zarzadzaniu jakościa [Analysis of multivariate binary processes as a method to support managerial decisions in quality management] (in:) Przedsiębiorcze aspekty rozwoju organizacji i biznesu [Business aspects of the development of organisation and business], ed. A. Chodyński, Oficyna Wydawnicza AFM, Kraków. 
Iwasiewicz A., Paszek Z., Steczkowski J. (1988), Sekwencyjne metody kontroli jakości [Sequential methods of quality control], Akademia Ekonomiczna w Krakowie, Kraków.

Kolonko J. (1980), Analiza dyskryminacyjna i jej zastosowania w ekonomii [Discriminant analysis and its application in economics], PWN, Warszawa.

Major M. (1997), Sterowanie procesem za pomoca kart kontrolnych sum skumulowanych [Process control with the use of cumulative sum control charts], Materiały konferencyjne z I Krajowej Konferencji Naukowej Materiałoznawstwo-Odlewnictwo-Jakość, vol. III Jakość, Kraków.

Major M. (2015a), Acceptance Control Charts, "Zeszyty Naukowe UEK”, no. 7.

Major M. (2015b), Karty kontrolne sum skumulowanych z możliwościa akceptacji procesu dla zmiennych diagnostycznych o rozkładzie Poissona [Acceptance cumulative sum control charts for Poisson diagnostic variables] (in:) Wielowymiarowość systemów zarządzania [Multidimensionality of management systems], ed. M, Giemza, T. Sikora, Wydawnictwo Naukowe PTTŻ, Kraków.

Major M. (2015c), Wielokryterialna ocena jakości typu produktu [A multi-criterial assessment of the quality of product design], Zeszyty Naukowe. Seria specjalna: Monografie nr 236, Wydawnictwo Uniwersytetu Ekonomicznego w Krakowie, Kraków.

Major M. (2016), Monitorowanie procesów w oparciu o karty kontrolne sum skumulowanych z możliwościa akceptacji procesu [Process monitoring based on acceptance cumulative sum control charts] (in:) Podejście procesowe w zarzadzaniu organizacjami [The process approach in managing organisations], ed. P. Wiech, Zarządzanie Procesami w Teorii i Praktyce, no. 5, Szczecin.

Major M. (2017), Karty kontrolne sum skumulowanych z możliwością akceptacji procesu. Przeglad podstawowych narzędzi [Acceptance cumulative sum control charts - an overview of basic tools], "Zeszyty Naukowe UEK", no. 5.

Montgomery D.C. (2009), Introduction to Statistical Quality Control, John Wiley \& Sons, Inc., 6th ed., USA.

Qiu P. (2013), Introduction to Statistical Process Control, Chapman \& Hall/CRC, London.

Słownik jakości - terminy i definicje $w$ zakresie jakości [Dictionary of quality - terms and definitions in quality] (1968), Europejska Organizacja Sterowania Jakością, Centralny Urząd Jakości i Miar, Roterdam 1965, Warszawa.

Słownik jakości (1980) [Dictionary of quality] (based on: Glossary of Terms Used in Quality Conrtol (EOQC), 4th ed. 1976), ed. H. Chojecki, L. Wasilewski, Wydawnictwo Naukowo-Techniczne, Warszawa.

Taksonomiczna analiza przestrzennego zróżnicowania poziomu życia w Polsce w ujęciu dynamicznycm (2000) [A taxonomic analysis of spatial diversity of the living standards in Poland - a dynamic depiction], ed. A. Zeliaś, Wydawnictwo AE w Krakowie, Kraków.

Wald A. (1945), Sequential Tests of Statistical Hypotheses, Annals of Mathematical Statistics, 16.

Wald A. (1947), Sequential Analysis, Wiley, New York.

Walesiak M. (2002), Uogólniona miara odległości w statystycznej analizie wielowymiarowej [Generalised distance measure in multivariate statistical analysis], Wydawnictwo AE im. Oskara Lanego we Wrocławiu, Wrocław.

Willmott A. J., Grimshaw P. N. (1969), Cluster Analysis in Social Geography (in:) Numerical Taxonomy, Academic Press, New York. 
Wishart D. (1969), Mode Analysis: A Generalization of Nearest Neighbor which Reduces Chaining Effects (in:) Numerical Taxonomy, ed. A. J. Cole, Academic Press, New York.

\section{Binaryzacja i monitorowanie procesów stochastycznych w zarządzaniu jakością (Streszczenie)}

Celem artykułu jest prezentacja problemów, z jakimi można się spotkać podczas monitorowania i oceny procesów sterowania jakością. W procedurach sterowania jakością wyróżnia się dwa rodzaje oceny właściwości produktów (procesów): alternatywną ocenę właściwości i liczbową ocenę właściwości. Z tego podziału wynika również podział procesów. Ogólnie istnieją dwa rodzaje procesów stochastycznych: procesy binarne i procesy ciągłe (liczbowe). Pierwsze z nich sprowadzają opisywaną rzeczywistość do systemu zero-jedynkowego, drugie zaś do analizy procesów wykorzystują zmienne losowe ciągłe.

W artykule poruszono między innymi następujące problemy: ocena wielowymiarowych procesów stochastycznych, sposoby binaryzacji procesów, pomiar jakości produktów (procesów), zastosowanie statystycznych procedur do monitorowania procesów. W opracowaniu zamieszczono także obszerny przykład numeryczny ilustrujący omawiane problemy.

Słowa kluczowe: procesy binarne, zarządzanie jakością, sterowanie procesem, ocena wielowymiarowych procesów stochastycznych. 